Original Article

\title{
VALIDATION OF REVERSED-PHASE HIGH-PERFORMANCE LIQUID CHROMATOGRAPHY METHOD FOR SIMULTANEOUS DETERMINATION OF 6-, 8-, 10-GINGEROLS AND 6-SHOGAOL FROM GINGER EXTRACTS
}

\author{
BENNY ANTONYa, MERINA BENNYa*, MARY RESHMAa
}

aResearch and Development Laboratory, Arjuna Natural Private Ltd., Erumathala P0, Aluva, Kerala, India 683112

Email: merina@arjunanatural.com

Received: 22 Nov 2019, Revised and Accepted: 12 Feb 2020

\begin{abstract}
Objective: Development and validation of a High-Performance Liquid Chromatography (HPLC) method for the simultaneous estimation of 6-, 8-, 10Gingerols and 6-Shogaol in ginger extract using authentic standards.
\end{abstract}

Methods: The chromatographic separation was achieved by using a C18 column and a mobile phase composed of acetonitrile, ortho-phospohoric acid in water and methanol. The proposed method was validated in terms of the analytical parameters such as specificity, accuracy, precision, linearity, range, the limit of detection (LOD) and limit of quantification (LOQ) according to ICH guidelines.

Results: Linear calibration curves were obtained over concentration ranges of 10-250 $\mu \mathrm{g} / \mathrm{ml}$ for 6-, 8-, 10-gingerols and 6-shogaol with determination coefficients more than 0.99 for each analyte. Intra and inter-day precisions of the method were found to be below $2 \%$ for each analyte, with relative standard deviation (\% RSD) values in the range of 0.47 to $1.55 \%$ for 6 -gingerol, 0.44 to $1.51 \%$ for 8 -gingerol, 0.24 to $1.90 \%$ for 10 -gingerol and 0.25 to $1.67 \%$ for 6 -shogaol. The percentage recovery of gingerols and shogaol was obtained with an average of $99.53 \%$, $99.97 \%$, $100.13 \%$ and $100.53 \%$ respectively, which was well within acceptance range.

Conclusion: Simple, accurate, precise and rapid HPLC method was developed for the simultaneous analysis of 6-, 8-, 10-gingerols and 6-shogaol and validated in accordance with ICH guidelines. The developed method was found to be suitable for the standardization of herbal extracts and polyherbal formulations for the content of 6-, 8-, 10-gingerols and 6-shogaol.

Keywords: 6-gingerol, 8-gingerol, 10-gingerol, 6-shogaol, Validation

(c) 2020 The Authors. Published by Innovare Academic Sciences Pvt Ltd. This is an open access article under the CC BY license (http://creativecommons.org/licenses/by/4.0/) DOI: http://dx.doi.org/10.22159/ijpps.2020v12i4.36446. Journal homepage: https://innovareacademics.in/journals/index.php/ijpps

\section{INTRODUCTION}

Ginger (Zingiber officinale Roscoe), a member of the family Zingiberaceae, that has been extensively used in traditional medicines [1-2]. The major constituents in ginger rhizomes are phenolic compounds, terpenes, polysaccharides, lipids, organic acids, and raw fibers. Terpene components of ginger include zingiberene, $\beta$ bisabolene, $\alpha$-farnesene, $\beta$-sesquiphellandrene, $\quad$ and $\alpha$-curcumene, while phenolic compounds include gingerol, paradols, and shogaol [35]. Gingerols are the most abundant compounds present in the fresh and dry roots of ginger. Gingerol compounds with varying chain lengths were reported from the species of which 6-gingerol is the most abundant form [6]. Gingerols possesses diverse biological activities including anti-inflammatory, antioxidant, anticancer, analgesic, gastroprotective, cardiotonic, antipyretic, anti-angiogenic, anti-platelet aggregation effects and anti-hyperglycemia [7-20]. There is great demand for 6-gingerol due to its low toxicity and attractive medicinal potential [21]. Shogaols, the dehydrated form of gingerols, are found only small quantities in fresh root and are mainly found in the dried and thermally treated roots [22, 23]. The most abundant form of shogaols is 6-shogaol and has many biological effects such as antibacterial, antifouling and antioxidant $[23,24]$.

USP method is widely used for the estimation of gingerols from ginger rhizome in which the reference standard used is capsaicin [25]. Several analytical methods including high-performance liquid chromatography (HPLC) have been employed for the estimation of different gingerols where 6-gingerol was used as a reference standard [1, 2, 26, 27]. Gingerols, being the major active components possessing various pharmacological and physiological effects, an accurate optimization of total gingerol is highly essential for formulating products using ginger extracts.

Hence, the present study was aimed at the development of a validated High-Performance Liquid Chromatographic method for the fast and simultaneous determination of 6-gingerol (6-G), 8-gingerol
(8-G), 10-gingerol (10-G) and 6-shogaol (6-S) in ginger extracts using authentic standard compounds.

\section{MATERIALS AND METHODS}

\section{Reagents and samples}

The reference standards of 6-gingerol, 8-gingerol, 10-gingerol and 6shogaol were purchased from Sigma-Aldrich, Germany. Acetonitrile and methanol were HPLC grade purchased from Merck, Germany. The water used in this study was ultrapure, obtained from a Milli- $Q$ RO system (Millipore Corporation, France). Ortho-phosphoric acid used for the experiment was of analytical grade and was purchased from Merck Specialties Private Limited, Mumbai, India. Ginger extracts were obtained from the commercial batch manufactured at Arjuna Natural Pvt. Limited, Aluva, Kerala.

\section{Instrumentation and chromatographic conditions}

Liquid chromatographic separations were performed on a binary HPLC (Waters) separation 2998 series, variable wavelength photodiode array (PDA) detector module equipped with autosampler 2707 with injection volume $20 \mu \mathrm{l}, 1525$ pump, column used was $\mathrm{C}_{18}$ Sunfire $(150 \times 4.6 \mathrm{~mm}, 5 \mu$ particle size $)$ and data recorded using Empower 3 software. The separation was carried out with the mobile phase consisting of acetonitrile, $(0.1 \%)$ orthophospohoric acid in water and methanol (55:44:1, v/v/v) at a flowrate of $1.0 \mathrm{ml} / \mathrm{min}$ and chromatograms were monitored at $282 \mathrm{~nm}$ with PDA detector.

\section{Preparation of standard solution}

Standard stock solutions of $6-\mathrm{G}, 8-\mathrm{G}, 10-\mathrm{G}$ and $6-\mathrm{S}$ were prepared by dissolving $10 \mathrm{mg}$ of 6-, 8-, 10-gingerols and 6-shogaol up to $10 \mathrm{ml}$ of methanol, to get stock solution containing $1000 \mu \mathrm{g} / \mathrm{ml}$ of $6-, 8-, 10-$ gingerols and 6-shogaol. From this, different aliquots were prepared to get known concentrations from $10-250 \mu \mathrm{g} / \mathrm{ml}$. 


\section{Preparation of sample solution}

Approximately, $125 \mathrm{mg}$ of Ginger extract-GOR-015 was weighted into a $25 \mathrm{ml}$ volumetric flask and dissolved in methanol by sonication for 1 minute. The solution was filtered through $0.2 \mu \mathrm{m}$ syringe filter and $20 \mu \mathrm{l}$ of the final sample was injected directly.

\section{Method validation}

The analytical method was validated as per ICH guidelines [28] for specificity, precision, accuracy, linearity, range, and limits of detection and quantification.

\section{Specificity}

Specificity is the ability to assess unequivocally the analyte in the presence of components that may be expected to be present, such as impurity, degradation products, and matrix components. In this study, the specificity was demonstrated by running blank, standard and sample solutions.

\section{Precision}

The precision of the method was investigated with respect to repeatability and intermediate precision. The repeatability (intraday precision) of the method was evaluated by assaying three replicate injections of the gingerols and shogaol standard at concentrations of $15,30,75$ and $200 \mu \mathrm{g} / \mathrm{ml}$ on the same day at different times. The percentage relative standard deviation (\%RSD) of the peak area and retention time was calculated. The intermediate precision (inter-day precision) was demonstrated by evaluating the relative peak area at four different concentration levels as taken in an intraday study that cover the assay method. The precision was expressed as \% RSD of the system and the samples analyzed in triplicate.

\section{Accuracy}

The accuracy was evaluated by means of recovery assays carried out by adding known amounts of the $6-\mathrm{G}, 8-\mathrm{G}, 10-\mathrm{G}$ and $6-\mathrm{S}$ standard solutions to the placebo samples, at three different levels $(80 \%$, $100 \%$, and $120 \%$ ) of the initial concentration of the sample. Standards, 6-G, 8-G, 10-G and 6-S were added to the samples at 50, 75 and $100 \mu \mathrm{g} / \mathrm{ml}$ of these compounds. Then the sample was prepared according to the sample preparation in triplicate. Average recoveries were calibrated by the formula recovery $(\%)=$ $\left\{\frac{\text { (amount found-original amount })}{\text { amount spiked }}\right\} \times 100$

\section{Linearity}

The linearity of measurement was evaluated by analyzing different concentrations $(10-250 \mu \mathrm{g} / \mathrm{ml})$ of the standard solutions. Calibration curve was constructed for gingerols and shogaol by plotting average peak area against concentration and regression equation. The correlation coefficient and the slope of the peak were also computed. All the samples were analyzed in triplicate.

\section{Sensitivity}

The limit of detection (LOD) and the limit of quantification (LOQ) were determined from the calibration curves of $6-G, 8-G, 10-G$ and 6 $\mathrm{S}$ standards. LOD was calculated according to the expression Limit of detection (LOD) and limit of quantitation (LOQ) were calculated using the formula LOD $=(3.3 \times \sigma) \div \mathrm{s}$ in which $\sigma$ is intercept standard deviation and $\mathrm{s}$ is the slope of the calibration curve. LOQ was established by using the expression LOQ $=(10 \times \sigma) \div \mathrm{s}$.

\section{Statistical analysis}

The data were analyzed by one-way analyses of variance (ANOVA) software. The data is presented as the mean \pm SD (standard deviation) and $p$ value $<0.05$ was considered as significant.

\section{RESULTS}

Liquid chromatographic separation of gingerols was carried out on a binary HPLC system (Waters 2998 series). Samples were separated on a Sunfire C18 column by using an isocratic solvent system composed of acetonitrile, $(0.1 \%)$ ortho-phospohoric acid in water and methanol $(55: 44: 1, v / v / v)$. The flow rate was constant at 1 $\mathrm{ml} / \mathrm{min}$ and the detection wavelength was set at $282 \mathrm{~nm}$. There is no interference was observed from diluents, impurities, or excipients present in the gingerol samples at $282 \mathrm{~nm}$. The developed method precisely separates the constituents with well-resolved peaks for gingerols and shogaol under these conditions.

\section{Specificity of the developed method}

The specificity of this method was determined by analysis of the blank, standard and sample solution chromatograms. Good separation between the peaks of 6-G, 8-G, 10-G and 6-S was achieved, with the retention times, $4.553 \mathrm{~min}$ for $6-\mathrm{G}, 9.754 \mathrm{~min}$ for 8-G, $23.947 \mathrm{~min}$ for $10-\mathrm{G}$ and $12.227 \mathrm{~min}$ for $6-\mathrm{S}$. No interference was observed at the retention time when chromatograms of blank, standard and sample were monitored (fig. 1).
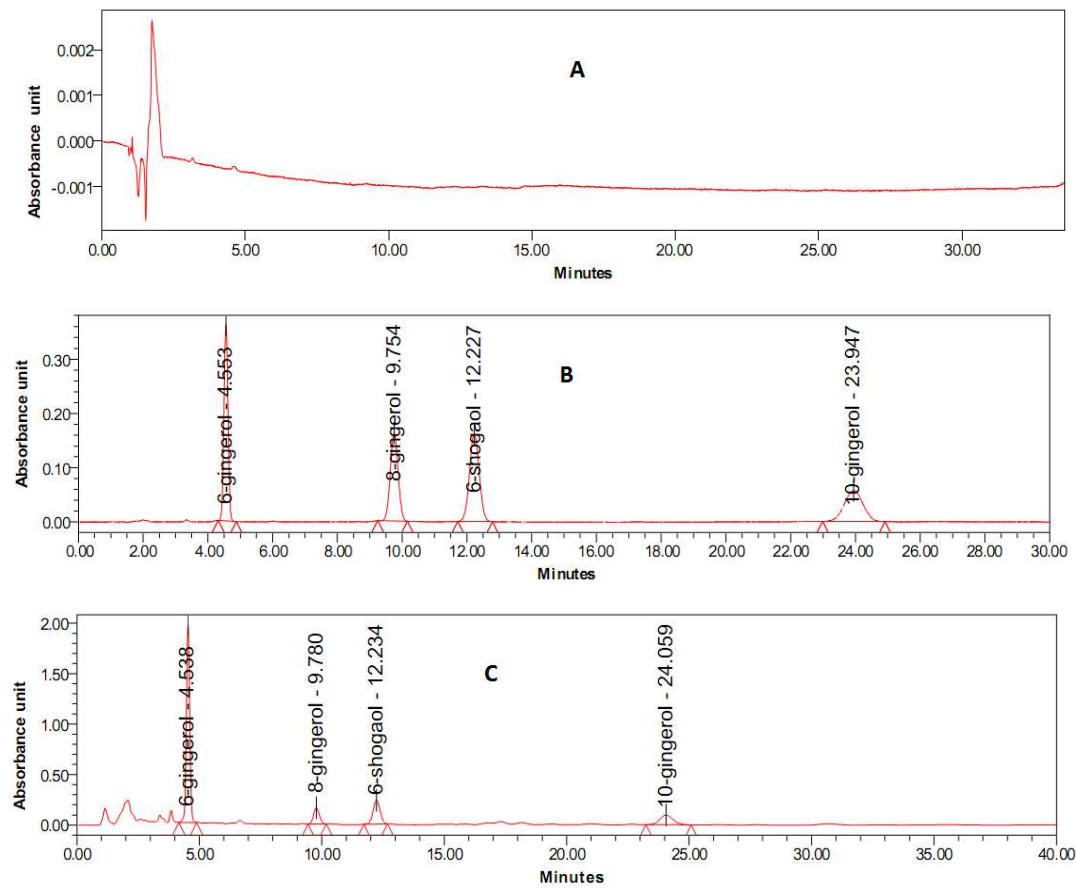

Fig. 1: Chromatograms of Blank (A), Standard (B) and Sample (C) 


\section{Linearity and range of the developed method}

For linearity studies, eight solutions in the range of $10-250 \mu \mathrm{g} / \mathrm{ml}$ for $6-\mathrm{G}$ 8-G, 10-G and 6-S were analyzed. Each concentration was made and analyzed in triplicate. The peak areas obtained against each concentration of the analytes were used to build a linear regression. Good linearity was observed over the above-mentioned range with linear regression equations $\mathrm{Y}=1.52 \mathrm{e}^{4} \mathrm{X}-3.06 \mathrm{e}^{4}$ for $6-\mathrm{G}, \mathrm{Y}=$ $1.36 \mathrm{e}^{4} \mathrm{X}-8.8 \mathrm{e}^{4}$ for $8-\mathrm{G}, \mathrm{Y}=1.01 \mathrm{e}^{4} \mathrm{X}-1.52 \mathrm{e}^{4}$ for $10-\mathrm{G}$ and $\mathrm{Y}=$ $1.09 \mathrm{e}^{4} \mathrm{X}+3.67 \mathrm{e}^{4}$ for $6-\mathrm{S}$ (X is the concentration of analyte in $\mu \mathrm{g} / \mathrm{ml}$ and $\mathrm{Y}$ is peak area). The value of the correlation coefficient was 0.998 for $6-\mathrm{G}$, 0.998 for $8-G, 0.998$ for $10-G$ and 0.995 for 6-S.

\section{Accuracy of the developed method}

This study was performed by adding known amounts of 6-G, 8-G, 10$\mathrm{G}$ and 6-S to the placebo samples. Three-level of solutions were made and having concentrations at 50, 75 and $100 \mu \mathrm{g} / \mathrm{ml}$ for $6-\mathrm{G}, 8-$
$\mathrm{G}, 10-\mathrm{G}$ and 6-S. The recovery ranges for 6-G 8-G, 10-G and 6-S were $99.54-99.88 \%$, 98.78-100.12\%, $99.37-100.82 \%$ and $99.87-101.10 \%$ respectively for all three spiked levels. The relative standard deviation ranged from $0.471-1.808 \%$ for $6-\mathrm{G}, 0.275-1.346 \%$ for $8-\mathrm{G}$, $0.855-1.543 \%$ for $10-\mathrm{G}$ and from $0.553-1.670 \%$ for $6-\mathrm{S}$.

\section{Precision of the developed method}

For the proposed analytical method, repeatability and intermediate precisions were calculated and reported in terms of relative standard deviation (\%RSD) in table 2. Intermediate precision and repeatability included data of interday and intraday analysis. The relative standard deviation ranged from $0.47-1.55 \%$ for $6-\mathrm{G}, 0.92$ $1.51 \%$ for $8-G, 0.24-1.90 \%$ for $10-G$ and $0.45-1.67 \%$ for $6-S$ for intraday analysis and $0.50-0.78 \%$ for $6-\mathrm{G}, 0.44-1.06 \%$ for $8-\mathrm{G}, 0.34$ $0.95 \%$ for $10-\mathrm{G}$ and from $0.25-1.00 \%$ for $6-\mathrm{S}$ for inter-day analysis. The low values of $\%$ RSD indicated the reproducibility of the method. The result showed that the developed method was precise.

Table 1: Accuracy data for 6-gingerol, 8-gingerol, 10-gingerol and 6-shogaol

\begin{tabular}{|c|c|c|c|c|}
\hline \multirow[t]{2}{*}{ Compound name } & Amount added & Mean recovered amount \pm SD & \multirow[t]{2}{*}{ Mean recovery \% } & \multirow[t]{2}{*}{ \% RSD } \\
\hline & $(\mu \mathrm{g} / \mathrm{ml})$ & $(\mu \mathrm{g} / \mathrm{ml})$ & & \\
\hline \multirow[t]{3}{*}{ 6-Gingerol } & 50 & $49.77 \pm 0.900$ & 99.54 & 1.808 \\
\hline & 75 & $74.907 \pm 0.353$ & 99.36 & 0.471 \\
\hline & 100 & $99.698 \pm 1.503$ & 99.7 & 1.508 \\
\hline \multirow[t]{3}{*}{ 8-Gingerol } & 50 & $49.390 \pm 0.665$ & 98.78 & 1.346 \\
\hline & 75 & $75.087 \pm 0.206$ & 100.12 & 0.275 \\
\hline & 100 & $100.014 \pm 1.129$ & 101 & 1.129 \\
\hline \multirow[t]{3}{*}{ 10-Gingerol } & 50 & $50.412 \pm 0.778$ & 100.82 & 1.543 \\
\hline & 75 & $74.531 \pm 0.637$ & 99.37 & 0.855 \\
\hline & 100 & $100.209 \pm 0.947$ & 100.21 & 0.945 \\
\hline \multirow[t]{3}{*}{ 6-Shogaol } & 50 & $50.550 \pm 0.844$ & 101.1 & 1.67 \\
\hline & 75 & $74.904 \pm 0.414$ & 99.87 & 0.553 \\
\hline & 100 & $100.626 \pm 0.903$ & 100.63 & 0.898 \\
\hline
\end{tabular}

Values are expressed as mean $\pm \mathrm{SD}, \mathrm{n}=3$

Table 2: Repeatability and intermediate precision of the proposed method as determined after three intraday and inter day replicate injections of samples at four different concentrations

\begin{tabular}{|c|c|c|c|c|c|}
\hline \multirow[t]{3}{*}{ Compound name } & \multirow[t]{3}{*}{ Nominal concentration $(\mu \mathrm{g} / \mathrm{ml})$} & \multicolumn{2}{|c|}{ Intraday precision } & \multicolumn{2}{|c|}{ Inter day precision } \\
\hline & & \multicolumn{2}{|c|}{ Measured concentration $(\mu \mathrm{g} / \mathrm{ml})$} & \multicolumn{2}{|c|}{ Measured concentration $(\mu \mathrm{g} / \mathrm{ml})$} \\
\hline & & Mean Conc. \pm SD & $\%$ RSD & Mean Conc. \pm SD & $\%$ RSD \\
\hline \multirow[t]{4}{*}{ 6-Gingerol } & 14.7 & $14.73 \pm 0.07$ & 0.47 & $14.76 \pm 0.11$ & 0.77 \\
\hline & 29.4 & $29.51 \pm 0.15$ & 0.52 & $29.48 \pm 0.23$ & 0.78 \\
\hline & 73.5 & $73.19 \pm 0.59$ & 0.81 & $73.75 \pm 0.54$ & 0.73 \\
\hline & 196 & $194.39 \pm 3.01$ & 1.55 & $195.48 \pm 0.97$ & 0.50 \\
\hline \multirow[t]{4}{*}{ 8-Gingerol } & 14.25 & $14.14 \pm 0.13$ & 0.92 & $14.27 \pm 0.15$ & 1.06 \\
\hline & 28.5 & $28.28 \pm 0.28$ & 0.99 & $28.42 \pm 0.12$ & 0.44 \\
\hline & 71.25 & $71.03 \pm 0.88$ & 1.24 & $71.27 \pm 0.34$ & 0.47 \\
\hline & 190 & $188.47 \pm 2.85$ & 1.51 & $189.74 \pm 1.11$ & 0.59 \\
\hline \multirow[t]{4}{*}{ 10-Gingerol } & 14.25 & $14.40 \pm 0.27$ & 1.90 & $14.25 \pm 0.14$ & 0.95 \\
\hline & 28.5 & $28.30 \pm 0.32$ & 1.11 & $28.46 \pm 0.15$ & 0.54 \\
\hline & 71.25 & $71.19 \pm 1.11$ & 1.56 & $71.58 \pm 0.38$ & 0.53 \\
\hline & 190 & $189.97 \pm 0.45$ & 0.24 & $190.69 \pm 0.64$ & 0.34 \\
\hline \multirow[t]{4}{*}{ 6-Shogaol } & 13.5 & $13.39 \pm 0.14$ & 1.05 & $13.53 \pm 0.12$ & 0.92 \\
\hline & 27 & $27.12 \pm 0.12$ & 0.45 & $27.01 \pm 0.27$ & 1.00 \\
\hline & 67.5 & $67.04 \pm 1.12$ & 1.67 & $67.15 \pm 0.17$ & 0.25 \\
\hline & 180 & $180.28 \pm 0.31$ & 0.31 & $180.30 \pm 0.45$ & 0.25 \\
\hline
\end{tabular}

Values are expressed as mean $\pm \mathrm{SD}, \mathrm{n}=3$

\section{Sensitivity of the developed method}

Limit of detection (LOD) and limit of quantitation (LOQ) were calculated using the formula $\operatorname{LOD}=(3.3 \times \sigma) \div \mathrm{s}$ and $\mathrm{LOQ}=$ $(10 \times \sigma) \div \mathrm{s}$, in which $\sigma$ is intercepted standard deviation and $\mathrm{s}$ is the slope of the calibration curve. The LOD values were $3.34,2.43,1.31$ and $1.14 \mu \mathrm{g} / \mathrm{ml}$ and the LOQ values were 10.12, 7.39, 3.99 and 3.45 $\mu \mathrm{g} / \mathrm{ml}$ for the simultaneous estimation of $6-\mathrm{G}, 8-\mathrm{G}, 10-\mathrm{G}$ and $6-\mathrm{S}$ respectively.

\section{DISCUSSION}

The HPLC method developed could achieved good separation and simultaneous estimation of gingerols and shogaols using Sunfire C18 column with a mobile phase composed of acetonitrile, $(0.1 \%)$ orthophospohoric acid in water and methanol $(55: 44: 1, v / v / v)$. The method is highly specific as there was no interference observed between chromatograms of blank, standard and sample. Good linearity with the coefficient of correlation 0.999 indicated that the proposed method was linear within the range $10-250 \mu \mathrm{g} / \mathrm{ml}$. The percentage recovery of gingerols and shogaol was obtained with an average of $99.53 \%, 99.97 \%, 100.13 \%$ and $100.53 \%$ respectively, which was well within the range of $98-102 \%$. The \% RSD for intraday and interday precisions of gingerols and shogaol were 0.77 , $0.93,0.89$ and 0.74 respectively. As per USP method, the percentage of total gingerol and 6-shogaol in ginger extract GOR-015 were found to be $16.26 \%$ and $1.12 \%$ respectively using capsaicin as 
standard [25]. According to the method described herein, the percentage of gingerols and 6-shogaol were determined to be $20.68 \%$ and $1.56 \%$ respectively in the same extract. The results showed acceptable precision of the method, with RSD values much lower than $2 \%$. The LOD and LOQ values showed the method was sensitive for the simultaneous estimation of 6-, 8-, 10-gingerols and 6-shogaol at low concentrations also.

\section{CONCLUSION}

Gingerols are the most important pharmacologically active components of ginger rhizomes. The present study is unique for the estimation of different gingerols, 6-gingerol, 8-gingerol, 10-gingerol and 6-shogaol using corresponding standards. The proposed analytical method is accurate, precise, linear, reproducible and within the range of acceptance as per ICH guidelines. The HPLC method developed can be adopted for the estimation of total gingerols present in the ginger extract and polyherbal formulations containing ginger.

\section{ACKNOWLEDGMENT}

The authors acknowledge all chemists in Arjuna Natural Pvt. Ltd. for their timely assistance and Mr. Abraham C V, Product Manager, Arjuna Natural Private Limited for help in statistical analysis.

\section{FUNDING}

Nil

\section{AUTHORS CONTRIBUTIONS}

Benny Antony and Merina Benny conceived the study and design the experiments. Mary Reshma performed the analysis and wrote the manuscript with input from all authors.

\section{CONFLICT OF INTERESTS}

Declared none

\section{REFERENCES}

1. Balladin DA, Headley O, Chang Yen I, McGaw DR. High pressure liquid chromatographic analysis of the main pungent principles of solar-dried West Indian ginger (Zingiber officinale Roscoe). Renew Energy 1998;13:531-6.

2. Zick SM, Ruffin MT, Djuric Z, Normolle D, Brenner DE. Quantitation of 6-, 8-and 10-gingerols and 6-shogaol in human plasma by high-performance liquid chromatography with electrochemical detection. Int J Biomed Sci 2010;6:233-40.

3. Grzanna R, Lindmark L, Frondoza CG. Ginger-an herbal medicinal product with broad anti-inflammatory actions. J Med Food 2005;8:125-32.

4. Prasad S, Tyagi AK. Ginger and its constituents: role in the prevention and treatment of gastrointestinal cancer. Gastroent Res Pract 2015;2015:142979.

5. Shukla $Y$, Singh M. Cancer preventive properties of ginger: a brief review. Food Chem Toxicol 2007;45:683-90.

6. Kajsongkram T, Rotamporn S, Limbunruang S, Sirinan T. Development and validation of a HPLC method for 6-gingerol and 6-shogaol in joint pain relief gel containing ginger (Zingiber officinale). Int J Med Health Biomed Bioeng Pharm Eng 2015;9:805-9.

7. Zhang M, Viennois E, Prasad M, Zhang Y, Wang L, Zhang Z, et al. Edible ginger-derived nanoparticles: a novel therapeutic approach for the prevention and treatment of inflammatory bowel disease and colitis-associated cancer. Biomaterials 2016;101:321-40.

8. Young HY, Luo YL, Cheng HY, Hsieh WC, Liao JC, Peng WH. Analgesic and anti-inflammatory activities of [6]-gingerol. J Ethnopharmacol 2005;96:207-10.

9. Nile SH, Park SW. Chromatographic analysis, antioxidant, antiinflammatory, and xanthine oxidase inhibitory activities of ginger extracts and its reference compounds. Ind Crop Prod $2015 ; 70: 238-44$.
10. Lee HS, Seo EY, Kang NE, Kim WK. [6]-Gingerol inhibits metastasis of MDA-MB-231 human breast cancer cells. J Nutr Biochem 2008;19:313-9.

11. Chakraborty D, Bishayee K, Ghosh S, Biswas R, Mandal SK, Khuda Bukhsh AR. [6]-Gingerol induces caspase 3 dependent apoptosis and autophagy in cancer cells: Drug-DNA interaction and expression of certain signal genes in HeLa cells. Eur J Pharmacol 2012;694:20-9.

12. Citronberg J, Bostick R, Ahearn T, Turgeon DK, Ruffin MT, Djuric Z, et al. Effects of ginger supplementation on cell-cycle biomarkers in the normal-appearing colonic mucosa of patients at increased risk for colorectal cancer: results from a pilot, randomized, and controlled trial. Cancer Prev Res 2013;6:271-81.

13. Shukla Y, Singh M. Cancer preventive properties of ginger: a brief review. Food Chem Toxicol 2007;45:683-90.

14. Young HY, Luo YL, Cheng HY, Hsieh WC, Liao JC, Peng WH. Analgesic and anti-inflammatory activities of [6]-gingerol. J Ethnopharmacol 2005;96:207-10.

15. Bhattarai S, Tran VH, Duke CC. Stability of [6]-gingerol and [6]shogaol in simulated gastric and intestinal fluids. J Pharma Biomed Anal 2007;45:648-53.

16. Akinyemi AJ, Thome GR, Morsch VM, Stefanello N, Goularte JF, Belló-Klein A, et al. Effect of dietary supplementation of ginger and turmeric rhizomes on angiotensin-1 converting enzyme (ACE) and arginase activities in L-NAME induced hypertensive rats. J Funct Foods 2015;17:792-801.

17. Suekawa M, Ishige A, Yuasa K, Sudo K, Aburada M, Hosoya E. Pharmacological studies on ginger. I. Pharmacological actions of pungent constituents,-gingeroland -shogaol. J Pharmacobiodyn 1984; 7:836-48.

18. Kim EC, Min JK, Kim TY, Lee SJ, Yang HO, Han S, et al. [6]-Gingerol, a pungent ingredient of ginger, inhibits angiogenesis in vitro and in vivo. Biochem Biophys Res Commun 2005;335:300-8.

19. Shih HC, Chern CY, Kuo PC, Wu YC, Chan YY, Liao YR, et al. Synthesis of analogues of gingerol and shogaol, the active pungent principles from the rhizomes of Zingiber officinale and evaluation of their anti-platelet aggregation effects. Int J Mol Sci 2014;15:3926-51.

20. Wei CK, Tsai YH, Korinek M, Hung PH, El-Shazly M, Cheng YB, et al. 6-Paradol and 6-shogaol, the pungent compounds of ginger, promote glucose utilization in adipocytes and myotubes, and 6paradol reduces blood glucose in high-fat diet-fed mice. Int J Mol Sci 2017;18-168.

21. Pawar N, Pai S, Nimbalkar M, Dixit G. RP-HPLC analysis of phenolic antioxidant compound 6-gingerol from different ginger cultivars. Food Chem 2011;126:1330-6.

22. Jolad SD, Lantz RC, Solyom AM, Chen GJ, Bates RB, Timmermann BN. Fresh organically grown ginger (Zingiber officinale): composition and effects on LPS-induced PGE2 production. Phytochemistry 2004;65:1937-54.

23. Bhattarai S, Tran VH, Duke CC. The stability of gingerol and shogaol in aqueous solutions. J Pharm Sci 2001;90:1658-64.

24. Ok S, Jeong WS. Optimization of extraction conditions for the 6shogaol-rich extract from ginger (Zingiber officinale Roscoe). Prev Nutr Food Sci 2012;17:166.

25. Maged H. Sharaf. United States Pharmacopiea 29-NF24; 2014. p. 2331.

26. Kajsongkram T, Otamporn SR, Limbunruang S, Thubthimthed S. Development and validation of a HPLC method for 6-gingerol and 6-shogaol in joint pain relief gel containing ginger (Zingiber officinale). Int J Med Health Biomed Bioeng Pharm Eng 2015;9:12.

27. Cafino EJ, Lirazan MB, Marfori EC. A simple HPLC method for the analysis of [6]-gingerol produced by multiple shoot culture of ginger (Zingiber officinale). Int J Pharmacogn Phytochem Res 2016;8:38-42.

28. International Conference on Harmonization ICH Q2 (R1), Validation of Analytical Procedures: Text and Methodology. The International Federation of Pharmaceutical Manufacturers and Associations, Geneva, Switzerland; 2005. 